\title{
Bioreactors for lignocellulose conversion into fermentable sugars for production of high added value products
}

\author{
Rossana Liguori $^{1} \cdot$ Valeria Ventorino $^{2} \cdot$ Olimpia Pepe $^{2} \cdot$ Vincenza Faraco $^{1}$
}

Received: 4 August 2015 /Revised: 22 October 2015 / Accepted: 26 October 2015 /Published online: 16 November 2015

(C) The Author(s) 2015. This article is published with open access at Springerlink.com

\begin{abstract}
Lignocellulosic biomasses derived from dedicated crops and agro-industrial residual materials are promising renewable resources for the production of fuels and other added value bioproducts. Due to the tolerance to a wide range of environments, the dedicated crops can be cultivated on marginal lands, avoiding conflict with food production and having beneficial effects on the environment. Besides, the agroindustrial residual materials represent an abundant, available, and cheap source of bioproducts that completely cut out the economical and environmental issues related to the cultivation of energy crops. Different processing steps like pretreatment, hydrolysis and microbial fermentation are needed to convert biomass into added value bioproducts. The reactor configuration, the operative conditions, and the operation mode of the conversion processes are crucial parameters for a high yield and productivity of the biomass bioconversion process. This review summarizes the last progresses in the bioreactor field, with main attention on the new configurations and the agitation systems, for conversion of dedicated energy crops (Arundo donax) and residual materials (corn stover, wheat straw, mesquite wood, agave bagasse, fruit and citrus peel wastes, sunflower seed hull, switchgrass, poplar sawdust, cogon grass, sugarcane bagasse, sunflower seed hull, and poplar
\end{abstract}

Rossana Liguori and Valeria Ventorino contributed equally to this work.

Vincenza Faraco

vfaraco@unina.it

1 Department of Chemical Sciences, University of Naples Federico II, Complesso Universitario Monte S. Angelo via Cintia 4,

80126 Naples, Italy

2 Department of Agriculture, University of Naples Federico II, Portici, Italy wood) into sugars and ethanol. The main novelty of this review is its focus on reactor components and properties.

Keywords Single and double helical ribbon impeller . Rushton impeller · S-shaped impeller · Anchor impeller . Pitched-blade impeller $\cdot$ Peg-mixer $\cdot$ Paddle blade magnetic impeller

\section{Introduction}

The use of crops as renewable sources of energy and compounds in alternative to fossil resources can promote a sustainable development avoiding the problems of shortage of fossil feedstock (Liguori et al. 2013; Kajaste 2014), but it generates problems in the agricultural market since their cultivation increases the lands subtracted to the food production and rising global food prices (Scheidel and Sorman 2012).

To limit the competition between the food- and the non food-crop lands, the cultivation of dedicated energy crops in marginal lands non appropriate for the traditional food crops is spreading throughout the world (Popp et al. 2014). It is noteworthy that the large-scale cultivation of dedicated crops, such as the perennial biomass Arundo donax, have favorable effects on the environment, since it improves soil fertility and reduces soil erosion (Fagnano et al. 2015). Moreover, lignocellulosic agro-industrial residual materials represent a further alternative of cheap sources to further minimize the conflict of food versus fuel. They avoid the displacement of food crops and the issues related to the deforestation, limiting the negative impacts on the environment (Iqbal et al. 2013).

Due to the high cellulose and hemicellulose contents (an average of 40 and $30 \%$, respectively) (Limayem and Ricke 2012), the dedicated crops and the residual materials can be converted in different value-added products, such as 
fermentable sugars (Mezule et al. 2015) and bioethanol or other bioproducts obtained by sugars fermentation (Shahsavarani et al. 2013). The complexity of the lignocellulosic macromolecular structure requires a bioconversion process consisting of three phases (Fig. 1). The first step is the biomass pretreatment needed to remove the lignin and make the polysaccharides more accessible to the further hydrolysis and it is considered generating the most negative impact on the environment, due to the high energetic inputs. The polysaccharides are then subjected to hydrolysis into monosaccharides mainly performed by hydrolytic enzymes during the second step, which is the most costly step of the overall process due to the high costs of the enzymes. In the last fermentation step, the fermentable sugars are converted into the targeted added value bioproducts (Jørgensen et al. 2007a).

Several efforts are under way to improve both the molecular systems, hydrolytic enzymes (Amore et al. 2012, 2013, 2015; Salmon et al. 2014; Weingartner Montibeller et al. 2014; Giacobbe et al. 2014), and microorganisms (Liguori et al. 2015; Ventorino et al. 2015), and bioreactor systems adopted for the biomasses bioconversion process in order to solve the environmental and economical issues of the process (Wang et al. 2011; Khoo 2015).

This review summarizes the last advances in the bioreactor field, with main focus on the new configurations and the agitation systems, for conversion of dedicated energy crops and residual materials into sugars and ethanol by separate hydrolysis and fermentation (SHF), simultaneous saccharification and fermentation (SSF), simultaneous saccharification and co-fermentation (SSCF) and consolidated bioprocessing (CBP) (Fig. 2).

The attention was focused on the dedicated crops Arundo donax (Table 1), corn stover (Table 2), wheat straw (Table 3) and other residual materials (Table 4). The main novelty of this review is its focus on reactor components and properties.

\section{Bioreactors for Arundo donax conversion}

\section{Production of sugars from SHF}

The energy crop Arundo donax was investigated by Palmqvist and Lidén (2012), in comparison with spruce, to evaluate the influence of water-insoluble solids (WIS) content on glucose yield during the hydrolysis. Both biomasses were steam pretreated and tested at WIS content of 10,15 , and $20 \%$. The process was performed in a 3-L stirred tank bioreactor (Belach Bioteknik, Stockholm, Sweden), supplied with an anchor impeller (Fig. 3a) (13-cm diameter and 2-cm blade width). The Cellic CTec2 (Novozymes, Denmark) $\left(0.1 \mathrm{~g}\right.$ solution $\mathrm{g}^{-1}$ WIS) was adopted as enzyme preparation. They tested two different methods, the first keeping constant the impeller speed at $10 \mathrm{rpm}$, and the second one keeping constant the impeller power input, in order to identify the best system to be applied for the hydrolysis of biomasses at high WIS concentration. They demonstrated that, at a fixed impeller speed of $10 \mathrm{rpm}$, the WIS content did not influence the energy input for Arundo donax, while a higher overall energy input was required for the hydrolysis of the spruce because, for the latter system, a strong correlation between initial WIS content and energy input was observed. This is explained by a quick drop in torque and viscosity that occurred during the saccharification of Arundo donax, as reported for other biomasses (Dasari et al. 2009), and that was much less noticeable for the spruce. In detail, when the impeller speed was kept constant and the WIS concentration was increased from 10 to $20 \%$, the glucose yield decreased from $\sim 40$ to $\sim 27 \%$ for Arundo donax and increased from $\sim 20$ to $\sim 30 \%$ for the spruce. Otherwise, when the impeller power was kept constant, the glucose yield was equivalent to that obtained at constant impeller speed for Arundo donax, while an opposite trend was observed for the spruce, since the glucose yield decreased from $\sim 45$ to $\sim 30 \%$ when the WIS content increase from 10 to $20 \%$. It could be due to a different shear force in the reactor between the two biomasses. Furthermore, Kadic et al. (2014) investigated the effect of agitation rate on the particle-size distribution (PSD) and glucan release during hydrolysis of the steam pretreated Arundo donax and spruce. The 2.5-L Biostat A and Biostat A Plus bioreactors (B. Braun Biotech International, Germany), equipped with a pitchedblade impeller with three blades at an angle of $45^{\circ}$ (diameter of $70 \mathrm{~mm}$ and a blade width of $20 \mathrm{~mm}$ ) (Fig. 3b), were used for the hydrolysis. Three impeller speeds 100, 300, and $600 \mathrm{rpm}$ were tested, evaluating their different effects on the biomass-particles mixing. In the case of spruce, the effects of agitation rate were only observed using high WIS content $(13 \%)$ at higher speed. In fact, no effects during the hydrolysis were observed at $13 \%$ of WIS at $100 \mathrm{rpm}$, but when the impeller speed was enhanced up to $600 \mathrm{rpm}$, an increase in the hydrolysis rate from 20 to $37 \%$ after $48 \mathrm{~h}$ took place. This could be explained as a result of strong reduction of particle size that improves the sugars released, increasing the hydrolysable surface area. Otherwise, for Arundo donax hydrolysis, a smaller particle size than spruce was observed both at low and high impeller speed; in spite of this, only a slight temporary effect (from $43 \%$ at $100 \mathrm{rpm}$ to $53 \%$ at $600 \mathrm{rpm}$ after $48 \mathrm{~h}$ ) on the hydrolysis rate at high WIS content (13\%) occurred. After $96 \mathrm{~h}$ of hydrolysis, the same rate of $\sim 60 \%$ was reached in both systems. To investigate if the reduction of particle size was caused by the enzymes action or by the agitation rate, further experiments in which the lignocellulose biomasses at $13 \%$ of WIS were agitated at high revolutions per minute without the enzymes addition were performed by Kadić et al. (2014). For the spruce, the effects of agitation rate on the particle size was strongly evident; in contrast, the reduction of particle size of Arundo donax was more influenced by the enzyme's action than the agitation rate, 
Fig. 1 Main steps of process of lignocellulosic biomass conversion

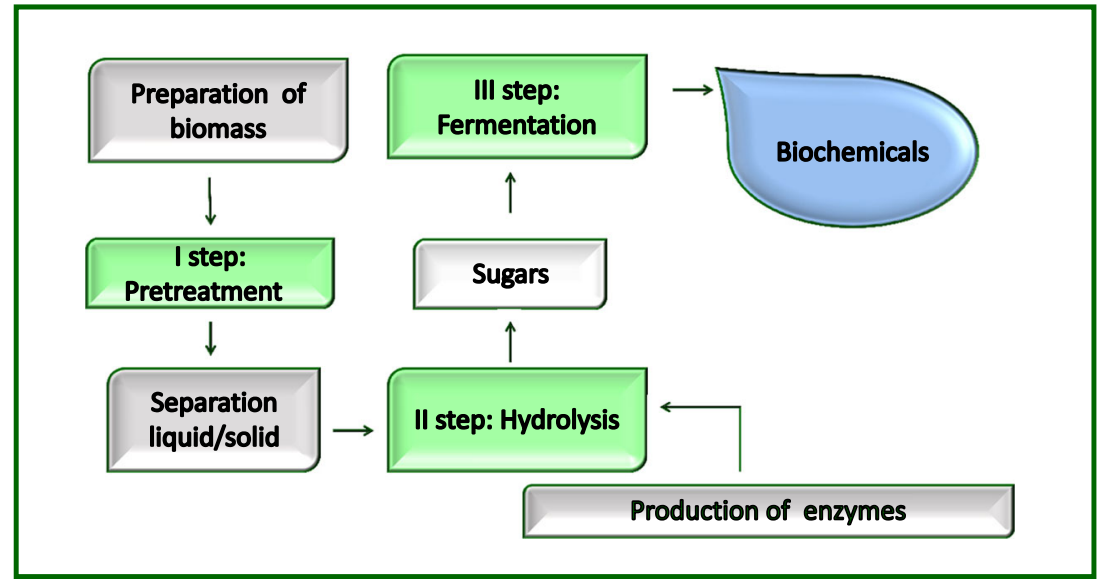

since the highest size reduction was only observed when the enzymes were loaded. Based on these results, it is important to choose the agitation speed based on the macromolecular structure of the lignocellulosic biomasses and the initial solids loading.

\section{Bioreactors for corn stover conversion}

\section{Production of sugars from SHF in batch operation mode}

The effect over the yield of sugars obtained during the hydrolysis of the sulfuric acid/steam pretreated corn stover employing two different reactor systems, the horizontal rotating bioreactor (HRR) and the vertical stirred-tank reactor (VSTR), was investigated by Du et al. (2014). The saccharification was performed by using the enzyme Cellic CTec2 from Novozymes, at loading of seven filter paper activity units per gram of dry matter (FPU $\mathrm{g}^{-1}$ ) at $50{ }^{\circ} \mathrm{C}$ in both reactor systems, equipped with thermostatic water bath. The material blending was assured by a mixing blade, at maximum constant rotation speed $(100 \mathrm{rpm})$ in the HRR system and by a double helical ribbon impeller (Fig. 3c), at variable speed in the VSTR system. During the hydrolysis, a more rapid viscosity reduction occurred in the HRR, allowing better cellulose degrading in comparison with the VSTR. Comparing the batch and fed-batch (adding biomass or biomass/enzymes) enzymatic hydrolysis, it was demonstrated that the best result of $86 \mathrm{~g}$ glucose $\mathrm{kg}^{-1}$ of dry matter was obtained after $87 \mathrm{~h}$ of incubation in the HRR through the batch hydrolysis in comparison with the value of $73 \mathrm{~g}$ glucose $\mathrm{kg}^{-1}$ of dry matter shown by the batch VSTR system.

It is well known that the use of ultrasound for lignocellulose treatment improves the enzymatic hydrolysis yield (Khanal et al. 2007; Nitayavardhana et al. 2008; MontalboLomboy et al. 2010a). Recently, Montalbo-Lomboy et al. (2010b) investigated the influence of the batch system over the saccharification sugars yield and the particles size of the corn slurry. The STARGEN ${ }^{\mathrm{TM}} 001$ from Genencor, at loading of 456 granular starch hydrolyzing units per gram of substrate (GSHU $\mathrm{g}^{-1}$ ), was added after sonication and was used as enzyme in the hydrolysis step for $3 \mathrm{~h}$ in a rotary shaker. The results showed a yield of reducing sugars obtained with the batch system equal to $1.6 \mathrm{~g} \mathrm{~L}^{-1}$.

The high solid processing of corn stover (PCS) represents one of the main drawbacks in the saccharification step. Even though an initial high PCS allows to obtain different advantages, like the reduction of reactor size, it is generally avoided due to the high viscosity shown and the high power required
Fig. 2 Processes of sugars and bioethanol production. SHF separate hydrolysis and fermentation, SSF simultaneous hydrolysis and fermentation, SSCF simultaneous saccharification and cofermentation of both hexoses and pentoses

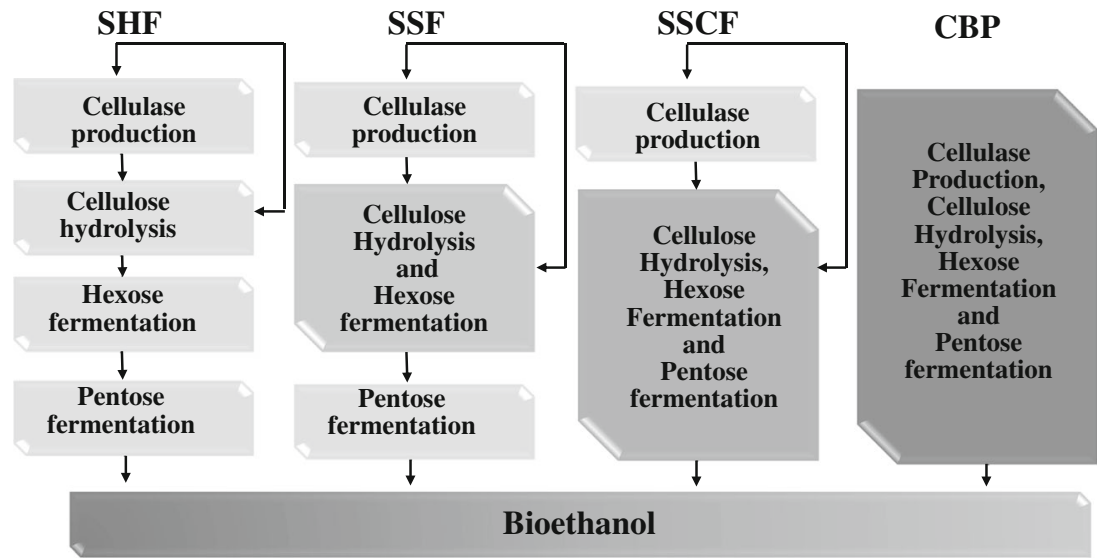


to mix homogenously the substrates. Dasari et al. (2009) designed a 8-L scraped surface bioreactor (SSBR), equipped with three scraping blades, to improve the saccharification of the corn stover at high initial PCS. They compared the glucose liberated in the process by using the bioreactor against the results obtained in 250-mL Erlenmeyer flasks. In this work, the saccharification was performed at $50{ }^{\circ} \mathrm{C}$ with $15 \mathrm{FPU}$ of Spezyme CP cellulase enzyme (Genencor) per gram of cellulose, at speed of $250 \mathrm{rpm}$ in flasks and $2 \mathrm{rpm}$ in bioreactor. The latter system allowed to reach a glucose yield of $60 \%$, a value $10 \%$ higher than that obtained in flasks $(50 \%)$ and, within the first hours of the hydrolysis reaction, a quick decrease in torque was observed, allowing a low-energy consumption. This was due to the random radial and angular mixing of the biomass and the homogeneous temperature generated by the horizontal rotation and the scraping of the blades.

It is well known that the enzymatic hydrolysis represents the limiting step of the overall costs of lignocellulose bioconversion process. Thus, several kinetic models to reduce both costs and efforts of the step were generated (Philippidis and Hatzis 1997; Gusakov et al. 1985; Sadana 1992; Kadam et al. 2004. One of them was elaborated and validated considering not only the reaction for conversion of cellulose into glucose and cellobiose, but also for the conversion of the cellobiose into glucose (Kadam et al. 2004). Moreover, parameters like enzyme adsorption, substrate reactivity, temperature, and sugar inhibition were taken into account. Following the model, the sulfuric acid-treated corn stover was saccharified with $45 \mathrm{mg}$ protein per gram of cellulose (CPN commercial cellulase, Iogen Corp., Ottawa, Canada) at $45^{\circ} \mathrm{C}$ in 250 -mL baffled Erlenmeyer flasks stirred at $130 \mathrm{rpm}$, or in stirred-tank reactor with impeller speed of $250 \mathrm{rpm}$. The results demonstrated that the model fitted well to predict the glucose yield both in flasks and in tank reactor. The maximum glucose concentration of around $50 \mathrm{~g} \mathrm{~kg}^{-1}$ of cellulose, after $168 \mathrm{~h}$, was obtained for both systems used. Although the temperature effect was not completely defined by the model, this could be exploited to optimize the saccharification process in silico.

\section{Production of sugars from SHF in fed-batch/continuous operation mode}

Montalbo-Lomboy et al. (2010b) investigated also the influence of the continuous-flow ultrasonic system over the saccharification sugars yield and the particle size of the corn slurry. Enzyme hydrolysis was performed in an ultrasonic reactor fitted with a donut-shaped horn using the same enzyme amount and process parameters described earlier. In addition, in this system, the corn slurry was localized in the center of the donut-shaped horn where the cavitation was more intense, increasing the liquefaction of the biomass. The results showed an increase up to 2-3 times of the sugars yield in the sonicated 


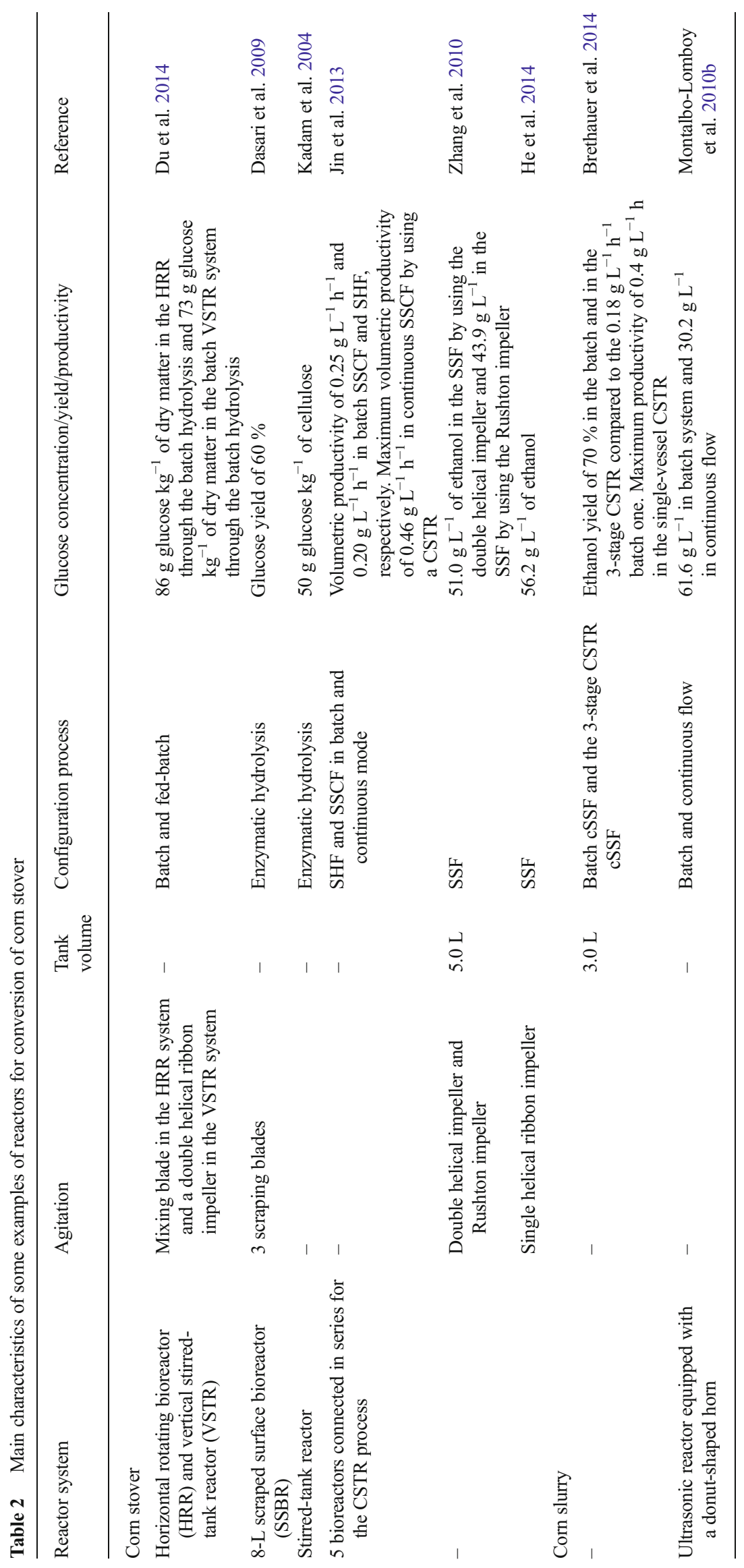




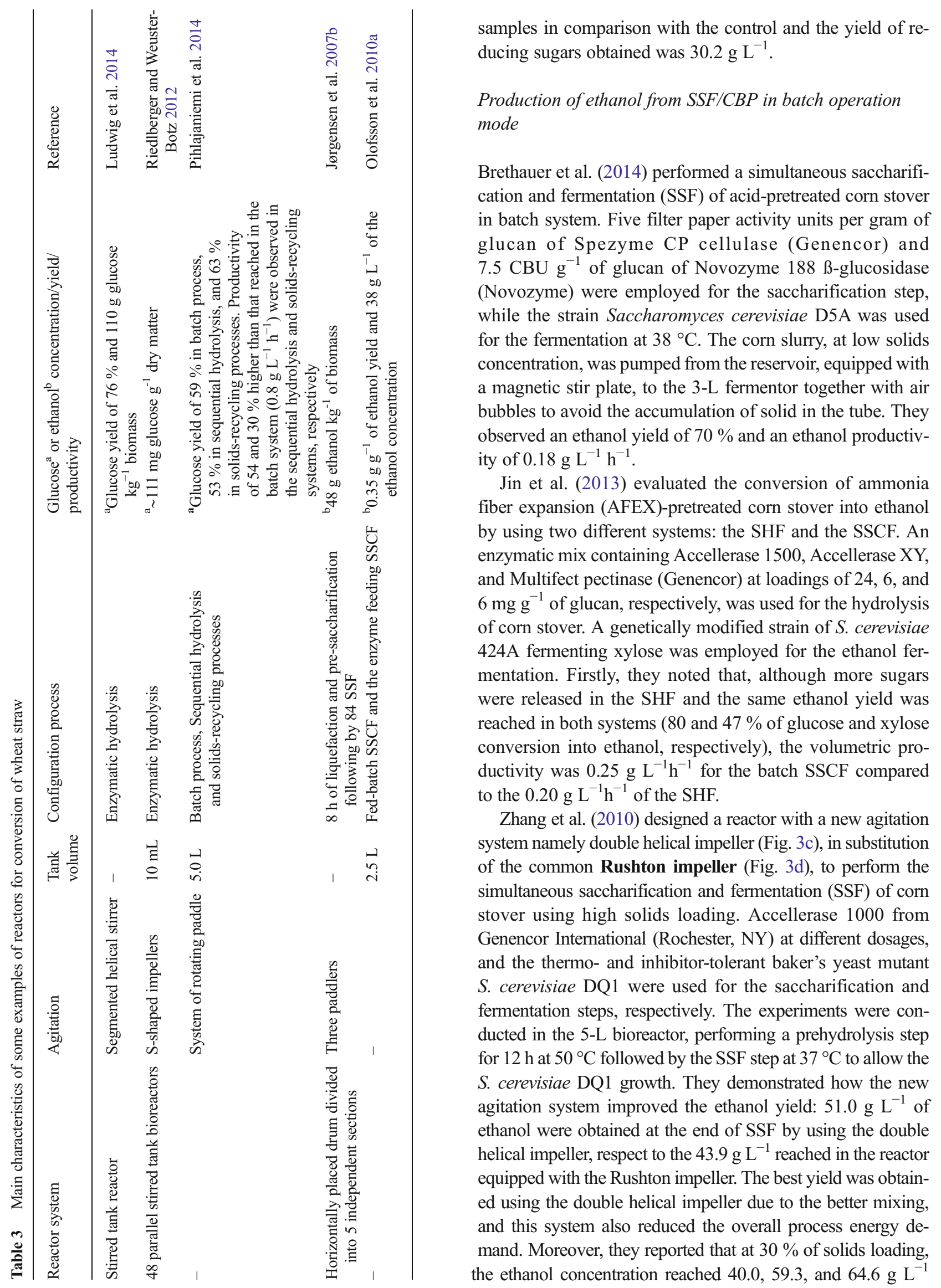




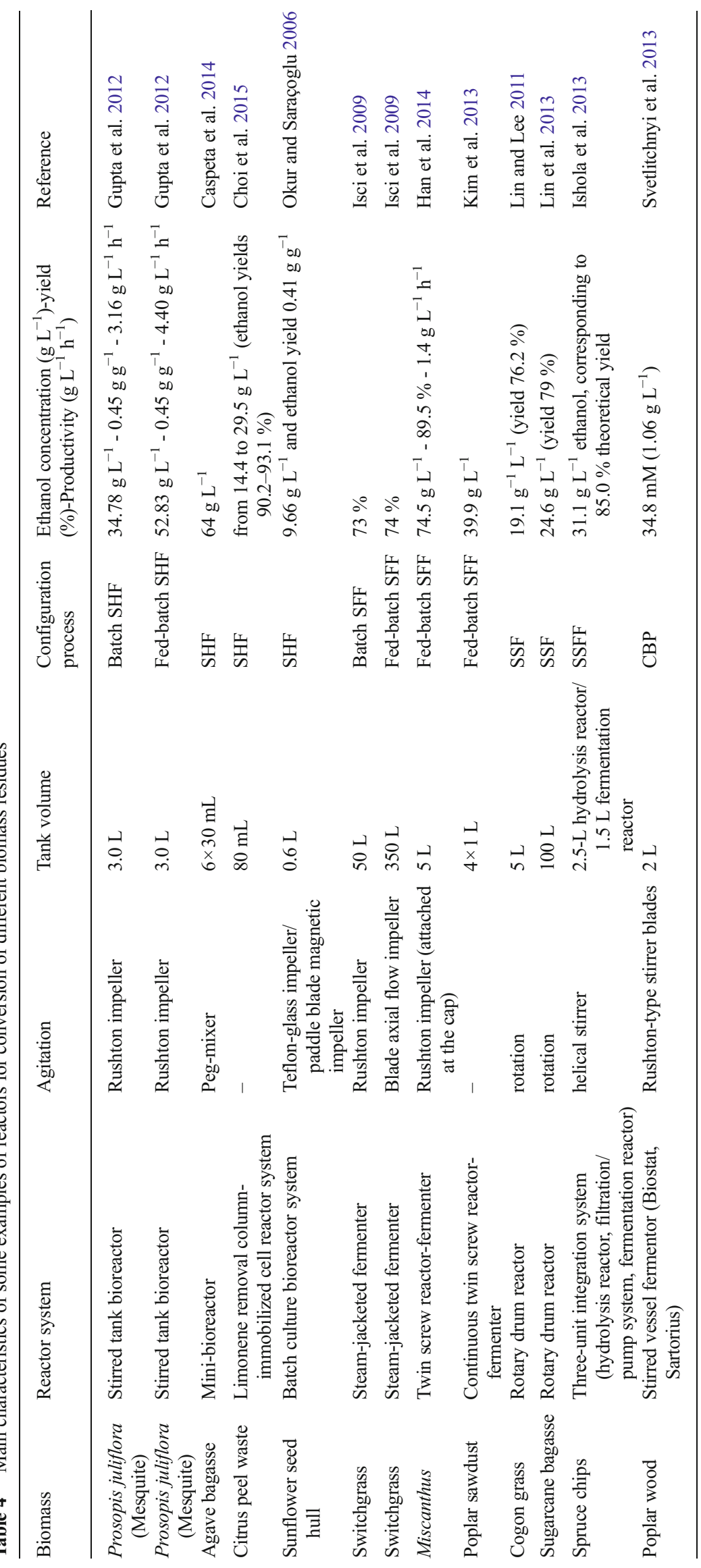


Fig. 3 Agitation systems used in the enzymatic hydrolysis and fermentation of lignocellulosic biomasses. a) Anchor impeller. b) Blade impeller with three blades at an angle of $45^{\circ}$. c) Double helical ribbon impeller. d) Rushton impeller. e) Single helical ribbon impeller. f) Segmented helical stirrer. g) Sshaped impellers. h) Rotating paddle. i) Three paddlers. I) peg mixer

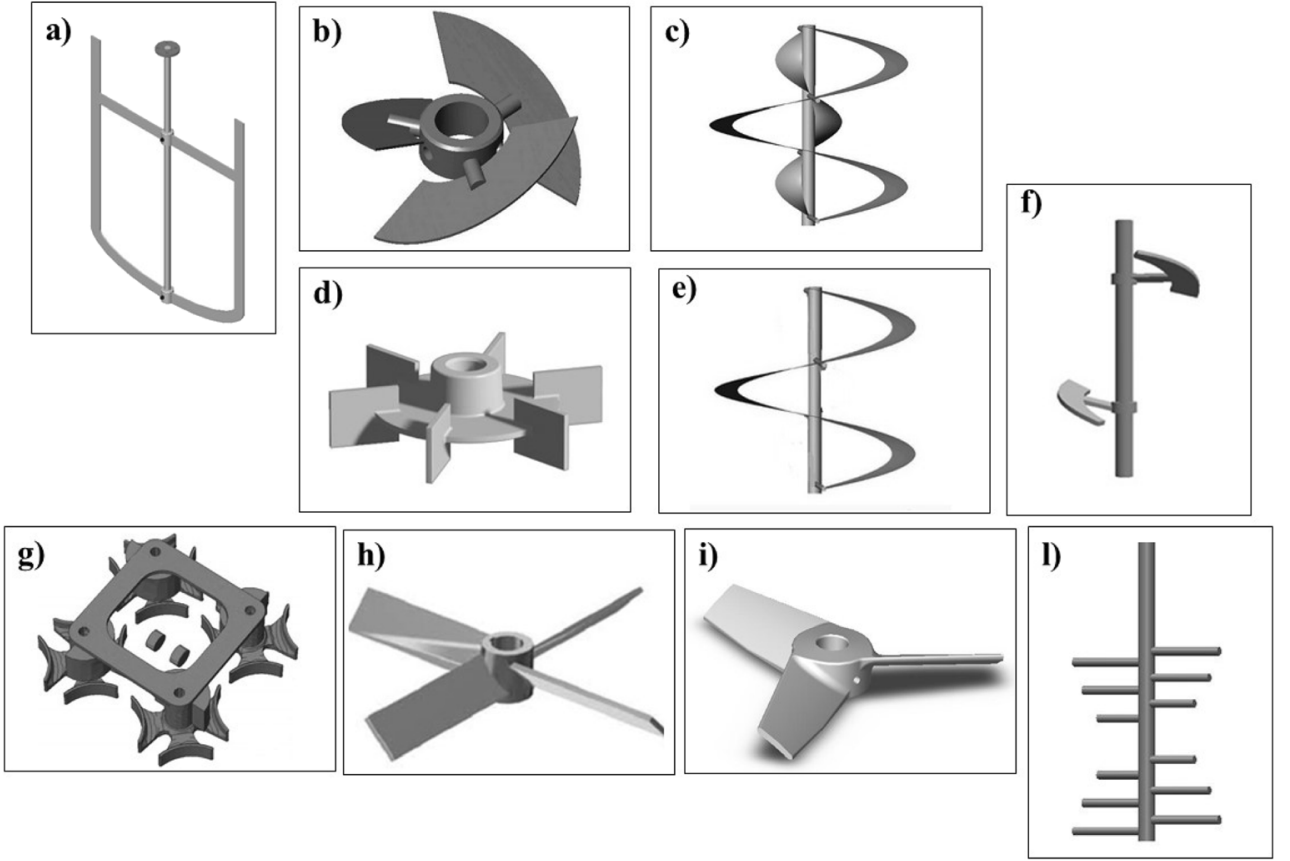

at enzyme dosages of 7.0, 15.0, and 30.0 $\mathrm{FPU} \mathrm{g}^{-1}$ of dry matter, respectively. Recently, He et al. (2014) performed the dry acid pretreatment of corn stover at high solids concentration by using a reactor equipped with a single helical ribbon impeller (Fig. 3e), demonstrating as the steady helically agitation leads to increase sugars and ethanol yields production. The corn stover was treated with $2.5 \% \mathrm{H}_{2} \mathrm{SO}_{4}$ for $3 \mathrm{~min}$ at $185{ }^{\circ} \mathrm{C}$ in agitation, followed by inoculation of the strain Amorphotheca resinae ZN1 (Chinese General Microorganisms Collection Center, Beijing, China; registration number: CGMCC 7452) to remove specific inhibitor compounds. Afterwards, the biodetoxified corn stover was hydrolyzed with the enzyme Youtell \#6 at a loading of $135 \mathrm{FPU} \mathrm{g}^{-1}$ of substrate, and fermented by the strain $S$. cerevisiae DQ1(Chinese General Microorganisms Collection Center, Beijing, China; registration number: CGMCC 2528). The SSF consisted of a $12 \mathrm{~h}$ of prehydrolysis at $50{ }^{\circ} \mathrm{C}$ and $\mathrm{pH} 4.8$, followed by a reduction of temperature at $37^{\circ} \mathrm{C}$ to promote the growth of the yeast and its sugars fermentation into ethanol. The results showed that the helical agitation during the pretreatment allows the increment of the sugars released during the hydrolysis, giving $81.9 \mathrm{~g} \mathrm{~L}^{-1}$ of glucose compared to the low value of $55.8 \mathrm{~g} \mathrm{~L}^{-1}$ obtained without mixing. As regards the ethanol production, $56.2 \mathrm{~g} \mathrm{~L}^{-1}$ were obtained after $48 \mathrm{~h}$ of fermentation instead of $44.4 \mathrm{~g} \mathrm{~L}^{-1}$ reached when no agitation was employed during the pretreatment.

\section{Production of ethanol from SSF/CBP in fed-batch/continuous operation mode}

Very few works about the simultaneous saccharification and fermentation (SSF) of corn stover in a continuous stirred tank reactor (CSTR) are available (Wooley et al. 1999; Jin et al. 2013), due to the limits related to the experimental troubles, although this system increases the volumetric productivity, mostly when more tank reactors are used (Brethauer and Wyman 2010). Brethauer et al. (2014) performed also a continuous simultaneous saccharification and fermentation (cSSF) of acid-pretreated corn stover using a 3-stage CSTR system. Hydrolysis and fermentation were performed in a 3-L fermentor as described earlier. They observed that at the same ethanol yield of $70 \%$, an ethanol productivity of $0.24 \mathrm{~g} \mathrm{~L}^{-1} \mathrm{~h}^{-1}$ was observed in the 3 -stage continuous system. Moreover, in $8 \mathrm{~h}$ of residence time, the single cSSF vessel reached the maximum ethanol productivity of $0.4 \mathrm{~g} \mathrm{~L}^{-1} \mathrm{~h}^{-1}$, a value that dropped when the total resident time was kept constant and the number of vessels was increased. In other experiment, when the total residence time was $24 \mathrm{~h}$, the productivity increased from 0.25 to $0.28 \mathrm{~g} \mathrm{~L}^{-1} \mathrm{~h}^{-1}$ when changed from one to three vessels, respectively.

Jin et al. (2013) evaluated the conversion of AFEX pretreated corn stover into ethanol also by continuous SSCF using a CSTR equipped with five bioreactors connected in series. The first reactor was used for the enzymatic hydrolysis at $50{ }^{\circ} \mathrm{C}, \mathrm{pH} 4.8$, and $800 \mathrm{rpm}$; then, the $24-\mathrm{h}$ prehydrolysate was pumped in the next reactor for the SSCF at $30{ }^{\circ} \mathrm{C}, \mathrm{pH}$ 5.5 , and $220 \mathrm{rpm}$. This system reached the highest volumetric productivity of $0.46 \mathrm{~g} \mathrm{~L}^{-1} \mathrm{~h}^{-1}$, value 2.3 and 1.8 higher than that observed in the batch SHF and SSCF, respectively. The use of high solids content of lignocellulose biomasses could decrease the loss of sugars, waste of water and steam generation, and also to lead an increment in the rate of bioconversion into ethanol (Kristensen et al. 2009). In spite of this, the 
high solids loading is related to operative issues as the high viscosity and the little free water, that limit the pretreatment method which can be performed (Modenbach and Nokes 2012).

\section{Bioreactors for wheat straw conversion}

\section{Production of sugars from SHF}

Several studies regarding the design of the bioreactor systems to be employed in the saccharification of the wheat straw at high solids loading and, that ensuring an effective mixing and a high bioconversion yield, were so far reported (Jørgensen et al. 2007a; Szijártó et al. 2011a, b). Ludwig et al. (2014) designed a new vertical stirred tank reactor supplied with a segmented helical stirrer (Fig. 3f) to hydrolyze the wheat straw, after alkaline-pretreatment, at high solids loading. Before testing the new system, they carried out a central composite response surface analysis to optimize the hydrolysis conditions, minimizing the enzyme dosage and maximizing the fiber concentration. The optimization was carried out in 250-mL Erlenmeyer flasks at $50{ }^{\circ} \mathrm{C}$ by using the Cellulase Cellic ${ }^{\circledR}$ CTec2 (Novozymes A/S) as hydrolytic enzyme. After $48 \mathrm{~h}$, a glucose yield of $70 \%$ was reached at the optimal solid concentration of $20 \%(w / w)$ and an enzyme dosage in the range of 20-30 $\mathrm{FPU} \mathrm{g}^{-1}$ dry matter. When the hydrolysis was performed in the new stirred reactor, at the same optimized conditions and at a speed of $80 \mathrm{rpm}$, the glucose yield was increased from 70 to $76 \%$, corresponding to a hydrolysate with $110 \mathrm{~g}$ glucose $\mathrm{kg}^{-1}$ biomass. The swelling of the fibers generated by the high hemicellulose content of the wheat straw did not allow exceeding the $20 \%(w / w)$ of dry matter. Riedlberger and Weuster-Botz (2012) reported an accurate high-throughput system suitable for acid or alkalinepretreated wheat straw, in order to reduce the costs for the optimization of the enzymatic hydrolysis step related to the large use of the enzymes required. The new system, consisting of 48 parallel stirred-tank bioreactors at volume of $10 \mathrm{~mL}$, was equipped with the novel S-shaped impellers (Riedlberger and Weuster-Botz 2010) (Fig. 3g). The homogenization of fibers at high solids loading was achieved by two permanent magnets (IBS Magnet, Berlin, Germany) that drove the rotation of the impeller around a fixed axis. Three different solid contents, 4,8 , and $10 \%(w / w)$ of pretreated dried wheat straw were saccharified with $15 \mathrm{mg}$ protein $\mathrm{g}^{-1}$ dry matter and $1.9 \mathrm{mg}$ protein $\mathrm{g}^{-1}$ dry matter of Celluclast ${ }^{\circledR}$ and Novozym ${ }^{\circledR}$ 188 (Novozymes A/S), respectively. After 9-h of hydrolysis, the glucose released ( $111 \mathrm{mg} \mathrm{g}^{-1}$ dry matter) using the highthroughput system was comparable to the 1-L scale. This test demonstrated the efficient and easy scale-up of the novel system that can be used for the optimization of pretreatment conditions. Other ways to reduce the costs of the saccharification process can be recycling the enzymes or the solid residues, exploiting the ability of adsorption onto lignin and cellulose fractions (Rodrigues et al. 2012; Lee et al. 1994). Pihlajaniemi et al. (2014) investigated the solids-recycling for the hydrolysis of the autohydrolysed wheat straw; moreover, they compared the hydrolysis yield and the volumetric sugars productivity obtained through the solids-recycling for the sequential and the batch reactions, at similar loading of enzymes, substrate, and total liquid. A commercial enzyme mix consisting of cellulase (Econase CE, AB Enzymes), $\beta$-glucosidase (Novozyme 188), and xylanase (GC 140, Genencor) was used for the hydrolysis. The reaction used at solids loading of $16 \%$ $(w / w)$ was carried out in a 5-L reactor composed by a horizontal cylinder and a system of rotating paddle (Fig. 3h), at speed rotation of $2 \mathrm{rpm}$. The hydrolysis yield was almost comparable among the three systems used, whereas differences were observed in the volumetric productivity. Hydrolysis yields of 56 and $59 \%$ were reached in the batch process at 48 and $72 \mathrm{~h}$, respectively. Similar values of $53 \%$ after $48 \mathrm{~h}$ and $63 \%$ after $72 \mathrm{~h}$ of reaction were obtained for both sequential hydrolysis and solids-recycling processes. Regarding the productivity, 1.4 and $0.8 \mathrm{~g} \mathrm{~L}^{-1} \mathrm{~h}^{-1}$ were obtained in 48 and $72 \mathrm{~h}$ of batch hydrolysis, respectively, using enzyme dose of $9 \mathrm{FPU} \mathrm{g}^{-1}$. Values of 54 and $30 \%$ higher were observed when the hydrolysis was performed in sequential hydrolysis or solids-recycling systems, at 48 and $72 \mathrm{~h}$, respectively. Although the hydrolysis yields were comparable and the productivity values were slightly lower at $72 \mathrm{~h}$ than at $48 \mathrm{~h}$ of the processes, both the solids-recycling and sequential hydrolysis system could be applied for an efficient enzymatic hydrolysis of the pretreated wheat straw.

\section{Production of ethanol from SSF/CBP in batch operation mode}

The use of lignocellulosic biomasses at solids loading above $15 \%(w / w)$ of dry matter is required in order to obtain an ethanol concentration more than $4 \%(w / w)$ and thus, making economically feasible the bioconversion process (Fan et al. 2003; Wingren et al. 2003). The high solids loading needs a mixing system to reduce the problematic related to the liquefaction and saccharification steps, like the initial viscosity and the high concentration of the inhibitory compounds. Jørgensen et al. (2007b) designed a reactor system useful for an efficient mixing during the liquefaction and saccharification of the pretreated wheat straw at low speed rates. A reactor consisted of a horizontally placed drum divided into five independently sections equipped by three paddlers (Fig. 3i) that were assembled around a horizontal rotating shaft. They investigated the effects over the liquefaction and glucose releasing varying the mixing speed and the initial dry matter content, carrying a liquefaction and saccharification steps for 96-h treatment; moreover, they evaluated the yield of ethanol after 8-h liquefaction and presaccharification followed by $84 \mathrm{~h}$ SSF. The enzyme cocktail consisting of 
Celluclast 1,5 FG L and Novozym 188 (Novozymes, Denmark) was used for the saccharification The mixing speed range tested was between 3.3 and $11.5 \mathrm{rpm}$, while the dry matter content went from 20 to $40 \%$. They observed that, after $24 \mathrm{~h}$ of treatment, the wheat straw structure was completely liquefied at low speed of $3.3 \mathrm{rpm}$. They also reported that the mixing speed did not influence the cellulose conversion in the tested range; differently, the hemicellulose conversion was influenced in a negative way, since it decreased $18 \%$ when the mixing speed increased from 3.3 to $11.5 \mathrm{rpm}$. Regarding the effect of the dry matter, they obtained a maximum of $86 \mathrm{~g}$ glucose $\mathrm{kg}^{-1}$ of biomass after $96 \mathrm{~h}$ of treatment at solid loading of $40 \%(w / w)$. As reported in other works (Ingesson et al. 2001; Lu et al. 2002; Tengborg et al. 2001), although the maximum glucose released was reached at the highest initial dry matter, a decrement of the bioconversion yield based on the total initial cellulose content, was observed when the dry matter was increased. When they evaluated the effect of different initial dry matter (from 2 to $40 \%(w / w)$ over the 84 SSF process, after $8 \mathrm{~h}$ of liquefaction and pre-saccharification at $50{ }^{\circ} \mathrm{C}$, the highest ethanol concentration of $48 \mathrm{~g} \mathrm{~kg}^{-1}$ of biomass was obtained at $35 \%(w / w)$ dry matter after $144 \mathrm{~h}$. According to other experiments (Mohagheghi et al. 1992; Devantier et al. 2005), a drop of the fermentation performance at value of dry matter higher than $35 \%(w / w)$ was observed, due to the stress conditions (i.e., high osmotic pressure, ethanol, and inhibitor concentration) determining the loss of viability of the yeast.

\section{Production of ethanol from SSF/CBP in fed-batch operation mode}

In order to obtain a high yield of ethanol from the bioconversion of the lignocellulosic biomasses, it is necessary to convert all the available sugars, hexoses and pentoses, that are both present in the macromolecular structure. Olofsson et al. (2010a) reported how the SSCF process of the acidpretreated wheat straw, combining the fed-batch and the enzyme feeding, improves the glucose and xylose cofermentation of the recombinant xylose-fermenting strain S. cerevisiae TMB3400 (Wahlbom et al. 2003). Through the process, the glucose was released at a very low rate, improving the xylose uptake by the yeast (Olofsson et al. 2008, 2010b). A 2.5-L bioreactors (Biostat A. B. Braun Biotech International, Melsungen, Germany; Biostat A plus; Sartorius, Melsungen) was used for the process in anaerobic conditions (Palmqvist et al. 1996). The saccharification of wheat straw was performed by using the enzyme mix consisting of the Xylanase XL (SAF-ISIS, Souston, France) and Novozyme 188 (Novozymes, Denmark). In all the SSCF experiments, the feed of the substrate was performed after $6,12,18$, and $24 \mathrm{~h}$, starting from the solids loading of $8 \%$ until reaching the value of $11 \%$. Regarding the enzymes feed, four different profiles, namely A, B, C, and D, were tested; in all cases, a low initial amount of enzyme was added to improve the liquefaction of the substrate. In the profiles A and B, the enzymes were added until 24 and $48 \mathrm{~h}$, respectively; instead, in the profiles $\mathrm{C}$ and $\mathrm{D}$, the enzymes were added for the first time during the last addition of the substrate and carried out until $48 \mathrm{~h}$. The profile $\mathrm{D}$ differs from $\mathrm{C}$ since at $24 \mathrm{~h}$ an additional feed of yeast was made, in order to evaluate if a high yield of ethanol could be achieved. As reference experiment, a SSCF in which the feeding of substrates was carried out as described earlier, while the total amount of the enzymes was added at the beginning of the process, was performed. In comparison with the reference experiment, while the other profiles did not gave improvements, profile $\mathrm{B}$ gave the best results, allowing an increment from 40 to $50 \%$ of the xylose conversion, from 0.31 to $0.35 \mathrm{~g} \mathrm{~g}^{-1}$ of ethanol yield and from 33 to $38 \mathrm{~g} \mathrm{~L}^{-1}$ of the final ethanol concentration.

\section{Bioreactors for other biomasses conversion}

\section{Production of sugars and ethanol from SHF in batch operation mode}

Gupta et al. (2012) exploited the saccharification and ethanol production of pretreated mesquite wood in batch experiment. Enzymatic hydrolysis of sodium chlorite-pretreated lignocellulosic biomass was performed in a 3.0-L stirred tank reactor (STR) equipped with Rushton impeller (Fig. 3d) for shaking (150 rpm), heating jacket and heat exchangers for temperature control $\left(50{ }^{\circ} \mathrm{C}\right)$, using $22 \mathrm{FPU} \mathrm{g}^{-1}$ of dry substrate (gds) of cellulase (Sigma-Aldrich) and $68 \mathrm{U} \beta$-glucosidase/gds (Sigma-Aldrich). Fermentation was performed at $30^{\circ} \mathrm{C}$, a constant speed of $200 \mathrm{rpm}$, and an aeration of $0.4 \mathrm{vvm}$, inoculating a $S$. cerevisiae strain to the hydrolyzed slurry after the addition of nutrients $\left(3 \mathrm{~g} \mathrm{~L}^{-1}\right.$ yeast extract, $0.25 \mathrm{~g} \mathrm{~L}^{-1}$ ammonium phosphate dibasic) with an initial pH 6.0. Enzymatic hydrolysis, performed using four different substrate loading values ( 5 , $10,15,20 \% \mathrm{w} / \mathrm{v}$ ) showed that a significant increment in sugars concentration was observed at increasing biomass concentration up to $15 \%$ (from 41.10 to $90.07 \mathrm{~g} \mathrm{~L}^{-1}$ ) declining thereafter at the highest substrate level $\left(80.78 \mathrm{~g} \mathrm{~L}^{-1}\right.$ with $40.39 \%$ cellulose conversion). After $11 \mathrm{~h}$ of fermentation, a concentration of $34.78 \pm 1.10 \mathrm{~g} \mathrm{~L}^{-1}$ (corresponding to a yield of $0.45 \mathrm{~g} \mathrm{~g}^{-1}$ and a productivity of $3.16 \mathrm{~g} \mathrm{~L}^{-1} \mathrm{~h}^{-1}$ ) was reached.

Innovative bioreactors were also developed to use wastes rich in lignocellulosics and residues from industrial and agricultural processes for bioethanol production. Caspeta et al. (2014) developed a system of six units of 30-mL minibioreactor (nominal volume) with a peg-mixer (Fig. 31) and a jacked-glass vessel with olives used for water circulating and temperature control during enzymatic hydrolysis, at $50{ }^{\circ} \mathrm{C}$, and sugar fermentations at $37^{\circ} \mathrm{C}$, to improve the SHF process of agave bagasse. Hydrolysis has been conducted using 15 FPU 
of Celluclast 1.5 L (NS50013, Novozymes) and 30 CBU of Novozyme 188 (NS50010, Novozymes) per gram of solids, at speed of $150 \mathrm{rpm}$ by a compact overhead stirrer. Using high solids loading $(20 \%, w / w)$, this system enhanced saccharification giving $120 \mathrm{~g} \mathrm{~L}^{-1}$ of glucose, corresponding to $80 \%$ of cellulose conversion after $24 \mathrm{~h}$ and a maximum glucose yield of $135 \mathrm{~g} \mathrm{~L}^{-1}$, corresponding to $90 \%$ cellulose conversion after $64 \mathrm{~h}$. Ethanol production reached values of $64 \mathrm{~L}^{-1}$ after $9 \mathrm{~h}$ of culture with $S$. cerevisiae strain SuperStart.

Direct conversion of fruit and citrus peel wastes (CPW) into bioethanol, without pretreatment, was investigated by Choi et al. (2015). Hydrolysis of CPW was performed using 12-16 and 10-25 $\mathrm{mg}$ protein $\mathrm{g}^{-1}$ fruit waste of two enzymes produced in-house from Aspergillus citrisporus (Korean Culture Center of Microorganisms KCCM6507) and Trichoderma longibrachiatum (Korean Collection for Type Cultures KCTC 6507), in citrate phosphate buffer ( $\mathrm{pH} 4.8$ ) at $45^{\circ} \mathrm{C}$ for $48 \mathrm{~h}$ at a speed of $180 \mathrm{rpm}$. Fermentation was conducted in continuous mode at $30^{\circ} \mathrm{C}$ in $80-\mathrm{mL}$ immobilized cell reactor (ICR) where $S$. cerevisiae cells was immobilized in alginate drops. A Dlimonene removal column (LRC), containing raw cotton and activated carbon, was also joined to the fermentation reactor for desorption of potentially inhibitor substances from the hydrolyzate. About $90 \%$ of CPW enzymatic conversion into fermentable sugars was reported after $48 \mathrm{~h}$. The CPW hydrolyzed was fed into the reactor from the feed stock by peristaltic pump at a flow of $0.08 \mathrm{~mL} \mathrm{~min}{ }^{-1}$. Fermentation in the LCR-ICR system resulted in high ethanol concentrations reaching values from 14.4 to $29.5 \mathrm{~g} \mathrm{~L}^{-1}$ (ethanol yields 90.2-93.1\%) that were 12-fold higher than ethanol values recovered in the ICR fermentation performed without LCR.

Okur and Saraçoglu (2006) reported that the aeration rate largely effected the ethanol formation from hydrolyzed crop residues in a bioreactor in uncontrolled $\mathrm{pH}$ conditions. Acid hydrolysis of sunflower seed hull, performed using a relatively low temperature $\left(90{ }^{\circ} \mathrm{C}\right)$ and low $\mathrm{H}_{2} \mathrm{SO}_{4}$ concentration $(0.7 \mathrm{M})$, allowed recovering approximately $90 \%$ of sugars from hemicellulose. Detoxified acid hydrolyzed, containing $35-40 \mathrm{~g} \mathrm{~L}^{-1}$ of total reducing sugars, was used for ethanol production with the yeast Pichia stipitis. Fermentation was performed in a batch culture bioreactor system consisting of a 0.6-L glass flask with a Teflon and silicone-lined top cap, a Teflon and glass impeller on the top cover, and a paddle blade magnetic impeller (Fig. 3c) on the bottom of flask. The fermentation process was carried out at $30{ }^{\circ} \mathrm{C}$ with agitation of $100 \mathrm{rpm}$ and the air was sparged by a flowmeter from the bottom of the vessel at different aeration rates $(0,2.88,5.76$, $\left.7.99 \mathrm{vv}^{-1} \mathrm{~min}^{-1}\right)$. Authors reported that oxygen supply stimulated yeast growth and ethanol formation although depending on aeration rate. In fact, the highest sugar consumption (78 \%), ethanol concentration $\left(9.66 \mathrm{~g} \mathrm{~L}^{-1}\right)$ and ethanol yield $\left(0.41 \mathrm{~g} \mathrm{~g}^{-1}\right)$ was reported at the lowest tested flow rate $\left(2.88 \mathrm{vv}^{-1} \mathrm{~min}^{-1}\right)$.
Production of sugars and ethanol from SHF in fed-batch operation mode

SHF fed-batch experiments were performed by Gupta et al. (2012) using pretreated Mesquite wood in comparison with the batch system described earlier. Enzymatic hydrolysis was carried out in a 3.0-L STR as described above with an initial solids concentration of $5 \%$ and adding $11 \mathrm{FPU} / \mathrm{gds}$ of cellulose, $34 \mathrm{U} \beta$-glucosidase/gds, and $5 \%$ of solids after 24,56 , and $80 \mathrm{~h}$. The use of a fed-batch system resulted in a further increase of sugars production $\left(127 \mathrm{~g} \mathrm{~L}^{-1}\right.$ with $63.56 \%$ cellulose conversion) of $56 \%$ respect to the batch system with a WIS content of $20 \%$. The highest sugars content resulted also in the highest ethanol concentration in fed-batch process. In fact, ethanol production of $52.83 \mathrm{~g} \mathrm{~L}^{-1}$ (ethanol yield and productivity of $0.45 \mathrm{~g} \mathrm{~g}^{-1}$ and of $4.40 \mathrm{~g} \mathrm{~L}^{-1} \mathrm{~h}^{-1}$, respectively) was observed.

\section{Production of ethanol from SSF/CBP in batch operation mode}

Switchgrass (Panicum virgatum L.) is adopted as a model energy crop by the US Department of Energy due to its high biomass yield, grown in different climate conditions and suitability for marginal land use (Kim et al. 2015); therefore different studies have focused on bioethanol production from this crop. Isci et al. (2009) performed SSF process of ammoniasoaked switchgrass using a 50-L (working volume) pilot-scale bioreactor. Pretreated switchgrass biomass soaked in ammonium hydroxide (containing $48 \%$ cellulose, $23 \%$ hemicellulose, and $22 \%$ Klason Lignin) has been directly used for SSF experiments in a 50-L steam-jacketed fermenter equipped with three Rushton-type impellers (Biostat U-50, Sartorius) (Fig. 3d). SSF was conducted at $35^{\circ} \mathrm{C}$ and $130 \mathrm{rpm}$ for $72 \mathrm{~h}$ after aseptical addition of yeast inoculum and $77 \mathrm{FPU} \mathrm{g}^{-1}$ cellulose of cellulase enzyme (Spezyme CP, Genencor Int.). At the end of the process, authors observed an ethanol yield of $73 \%$.

Rotary drum reactor represents another interesting strategy to improve the homogenization of pretreated lignocellulosic biomass in SSF. Lin and Lee (2011) used this technology to optimize the SSF process of alkaline-pretreated cogon grass. Pretreated biomass was loaded at a quantity of $1 \mathrm{~kg}(10 \%$ WIS concentration, $w / w$ ) in a 5 -L rotary drum reactor and SSF process has been run using $0.258 \mathrm{~mL} \mathrm{~g}^{-1}$ WIS of enzyme Accellerase 1500 and Ethanol Red dry S. cerevisiae yeast ( $1 \mathrm{~g} \mathrm{~L}^{-1}$ dry yeast) at $37^{\circ} \mathrm{C}$ and initial $\mathrm{pH}$ of 5.0. The reactor was rotated at $5 \mathrm{rpm}$ for $1 \mathrm{~min}$ at $0,24,48$, and $72 \mathrm{~h}$. An ethanol concentration of $19.1 \mathrm{~g} \mathrm{~L}^{-1}$ has been obtained corresponding to $76.2 \%$ of the theoretical ethanol yield.

These results were confirmed scaling up SSF process in a 100 -L rotary drum reactor using alkaline-pretreated sugarcane bagasse (Lin et al. 2013). The reactor was arranged by a double-cone rotary reactor providing a double-wall structure 
for controlling temperature by circulating either cold or hot water between the double walls. Moreover, it was equipped with waveshaped baffles along the inner wall surface of the vessel and with $\mathrm{CO}_{2}$ outlet port. In this reactor, $10 \mathrm{~kg}$ of alkaline-pretreated sugarcane bagasse (WIS concentration of $10 \%, w / w$ ) has been processed by SSF at $42^{\circ} \mathrm{C}$ for $72 \mathrm{~h}$ by using a commercial cellulase Accellerase $1000\left(0.2 \mathrm{~mL} \mathrm{~g}^{-1}\right.$ WIS $)$ and Kluyveromyces marxianus var. marxianus $\left(0.5 \mathrm{~g} \mathrm{~L}^{-1}\right)$. The reactor was rotated at $5 \mathrm{rpm}$ for $1 \mathrm{~min}$ only at the beginning of the process and every $24 \mathrm{~h}$. After $72 \mathrm{~h}, 24.6 \mathrm{~g} \mathrm{~L}^{-1}$ of ethanol concentration (79.0\% ethanol yield) were obtained.

A particular reactor system has been set up by Ishola et al. (2013) using simultaneous saccharification, filtration and fermentation (SSFF) process. This system included three integrated units: hydrolysis and fermentation vessels among which fermentation broth was circulated by filtration system. In particular, pretreated spruce chips $\left(\mathrm{SO}_{2}\right.$-catalized steam explosion) with $10 \%$ suspended solids (SS) was mixed with $35 \mathrm{FPU} \mathrm{g}^{-1} \mathrm{SS}$ of the commercial enzyme Cellic ${ }^{\circledR} \mathrm{CTec} 3$ (Novozymes) in a 2.5-L reactor (Infors AG107504, Minifors, Switzerland) and pre-hydrolyzed for $24 \mathrm{~h}$ at $50{ }^{\circ} \mathrm{C}, \mathrm{pH} 5.0$, and agitation of $500 \mathrm{rpm}$. During SSFF process, hydrolyzed slurry was continuously pumped at flow of $0.8 \mathrm{~L} \mathrm{~min}^{-1}$ in the fermentation vessel (1.5-L bioreactor, Biostat ${ }^{\circledR} \mathrm{B}$ plus 8843414 Sartorius, Germany) by a cross-flow membrane and simultaneously, the flow of the liquid of fermentation vessel was inverted to the hydrolysis reactor. Moreover, with the aim to equilibrate the uptake in the fermentation reactor, another peristaltic pump pushed the permeate out of the filter module by increasing flow rate from 1.1 to $2.9 \mathrm{~mL} \mathrm{~min}^{-1}$. To ensure yeast culture sedimenting, the fermentation bioreactor was equipped with a settler. The SSFF process was conducted for $96 \mathrm{~h}$ and $31.1 \pm 1.2 \mathrm{~g} \mathrm{~L}^{-1}$ ethanol (theoretical yield of $85.0 \%$ ) were reached.

Svetlitchnyi et al. (2013) used consolidated bioprocessing (CBP) approach for producing ethanol from poplar wood through thermophilic bacteria without the need for additional cellulolytic enzymes. In particular, washed and unwashed solid fraction of poplar wood obtained after dilute sulfurous acid steam explosion were loaded in 2-L stirred vessel fermentor (Biostat B-DCU, B. Braun/Sartorius AG) equipped with double jackets for temperature control, two Rushton type stirrer blades (Fig. 3d), pH control loops and high-precision blow-off valves for pressure controlling in a range of $1.3-1.5$ bar. CBP process was conducted at a constant $\mathrm{pH}$ of 6.75 and temperature of $72{ }^{\circ} \mathrm{C}$, inoculating the cellulolytic/xylanolytic strain Caldicellulosiruptor sp. DIB 004C (GenBank accession number JX988415) and the fermenting thermophilic ethanologenic/xylanolytic strain Thermoanaerobacter DIB 097X (GenBank accession number JX988424) in monocultures and in dual co-cultures. Authors reported that the CBP approach with operating temperatures above $70{ }^{\circ} \mathrm{C}$ and developing co-cultures of these bacterial strains led to an efficiently conversion of C6- and C5-sugars from pretreated lignocellulosic material into ethanol (up to $34.8 \mathrm{mM}$ ) and other products $(33.6 \mathrm{mM})$ such as lactate and acetate.

\section{Production of ethanol from SSF in fed-batch operation mode}

Isci et al. (2009) scaled up SSF process of ammonia-soaked switchgrass using a 350-L steam-jacketed fermenter equipped with three-blade axial flow impeller (Model PTT, Walker Stainless Equipment Co.). The process was carried out at $200 \mathrm{rpm}$ for $120 \mathrm{~h}$ in semiaseptic and fed-batch conditions, adding pretreated ammonia-soaked switchgrass biomass at three times $(0,5$, and $24 \mathrm{~h})$ to allow the thinning of substrate by cellulase ( $77 \mathrm{FPU} \mathrm{g}^{-1}$ cellulose). Controlling bacterial contamination during the process and improving stirring conditions of pretreated lignocellulosic biomass, it is possible to enhance bioethanol production ensuring the success of SSF scale-up. In fact, authors reported that in the best case in 350-L fermenter the ethanol yield was $74 \%$, similar to that obtained in 50-L fermenter (ethanol yield $73 \%$ ).

Han et al. (2014) developed SSF reactor to generate highconcentration bioethanol from Miscanthus biomass. They used a continuous twin-screw extruder for pretreating lignocellulosic biomass. The pretreatment reactor was fed with Miscanthus biomass at a rate of $18 \mathrm{~g} \mathrm{~min}^{-1}$ and pretreatment solution at $90 \mathrm{~mL} \mathrm{~min}^{-1}$. During this process, performed using a deficient amount of $\mathrm{NaOH}$ at $95{ }^{\circ} \mathrm{C}$ with a rotation of $80 \mathrm{rpm}$, solid and liquid components were separated using an oil press to reuse the solution obtained after pretreatment. This approach allowed reducing the costs of pretreatment process minimizing wastewater and reducing the amount of expensive alkali catalysts used. The resulting pretreated biomass was continuously fed at a rate of $80-150 \mathrm{~g} \mathrm{~h}^{-1}$ into the bottom of a 5-L tank reactor for SSF until to achieve a final concentration of approximately $25 \%(w / v)$, containing a glucose concentration of $40 \mathrm{~g} \mathrm{~L}^{-1}$. SSF process has been conducted at $32{ }^{\circ} \mathrm{C}$ with agitation $(90 \mathrm{rpm}$ ) for $96 \mathrm{~h}$ using an enzymatic loading of $30 \mathrm{FPU} \mathrm{g}^{-1}$ cellulose (Cellic ${ }^{\circledR} \mathrm{CTec} 2$, Novozymes), $15 \%$ Cellic $^{\circledR}$ HTec2 (Novozymes) and $7 \%$ $(v / v) S$. cerevisiae CHY 1011. The optimized pretreatment process coupled to a fed-batch approach increased the efficiency of hydrolytic enzymes obtaining ethanol at high concentration (up to $74.5 \mathrm{~g} \mathrm{~L}^{-1}$ with a yield and productivity of $89.5 \%$ and $1.4 \mathrm{~g} \mathrm{~L}^{-1} \mathrm{~h}^{-1}$ ) using high solid loadings lead to a reduction of distillation energy costs.

Similar approach was also assayed by Kim et al. (2013) that used a continuous twin screw-driven reactor (CTSR) pretreatment associated to a fed-batch SSF for bioethanol production from poplar sawdust. The reactor was composed of 30 segments for continuous biomass rotation, pulverization, and pressure. In this case, diluted $\mathrm{H}_{2} \mathrm{SO}_{4}(4 \%)$ was used as catalyst in the pretreatment process conducted at $180{ }^{\circ} \mathrm{C}$ with a screw rotation speed of $60 \mathrm{rpm}$ and biomass feeding rate of 
$1 \mathrm{~g} \mathrm{~min}^{-1}$. Fed-batch SSF experiments were conducted using 30 FPU of Celluclast $1.5 \mathrm{~L}$ (Novozymes) and $70 \mathrm{pNPG}$ Novozyme 188 (Novozymes) per gram of cellulose in a bioreactor composed of four units of $1 \mathrm{~L}$ in which $6.0 \mathrm{wt} \%$ pretreated biomass was added at three stages, maintaining a constant solids concentration. This approach showed a great potential since high ethanol concentration $\left(39.9 \mathrm{~g} \mathrm{~L}^{-1}\right)$ was achieved.

\section{Conclusions}

This review gives an overview of the last advances in the bioreactor configurations used for the conversion of dedicated energy crops and residual materials, describing how parameters like high solids loading, particles size, enzymes recycling, speed/power input, volume, and substrates reactivity, can improve the sugars release and the ethanol concentration. In the last decade, due to the complexity of the lignocellulose macromolecular structure, new bioreactor configurations have been designed and/or applied in order to make feasible the use of high substrate loading during the bioconversion process. Bioreactors equipped with new agitation systems like a special segmented helical stirrer (Ludwig et al. 2014), the S-shaped impellers (Riedlberger and Weuster-Botz 2012) and the double helical ribbon impeller (Du et al. 2014) were constructed to achieve an efficient fiber homogenization, reducing the required energy in conditions of high substrate loading. These agitation configurations enhance the homogeneous mixing of the biomass counteracting the elevate initial viscosity, due to the high biomass dosage, and allowing to profit several advantages related to this condition. As a matter of fact, a high substrate loading can lead to several economic and operative advantages such as the reduction of reactor size, the decrease in the sugars loss and wastes generation and easier downstream processing, due to higher product concentration. However, further developments in the bioreactor configuration combined to new efficient agitation systems and optimal operative conditions are needed to apply the process in pilot or industrial scale and to achieve a high bioconversion yield.

Acknowledgments This work was supported by grant from the Ministero dell'Università e della Ricerca Scientifica - Industrial research project "Development of green technologies for production of BIOchemicals and their use in preparation and industrial application of POLImeric materials from agricultural biomasses cultivated in a sustainable way in Campania region (BioPoliS)" PON03PE_00107_1, funded in the frame of Operative National Programme Research and Competitiveness $2007-$ 2013 D. D. Prot. N. 713/Ric. 29/10/2010.

Compliance with ethical standards All of the authors confirm that ethical principles have been followed in the research as well as in manuscript preparation.
Conflict of interest The authors declare that they have no competing interests.

Open Access This article is distributed under the terms of the Creative Commons Attribution 4.0 International License (http:// creativecommons.org/licenses/by/4.0/), which permits unrestricted use, distribution, and reproduction in any medium, provided you give appropriate credit to the original author(s) and the source, provide a link to the Creative Commons license, and indicate if changes were made.

\section{References}

Amore A, Pepe O, Ventorino V, Birolo L, Giangrande C, Faraco V (2012) Cloning and recombinant expression of a cellulase from the cellulolytic strain Streptomyces sp. G12 isolated from compost. Microb Cell Fact 11:164-178. doi:10.1186/1475-2859-11-164

Amore A, Pepe O, Ventorino V, Birolo L, Giangrande C, Faraco V (2013) Industrial waste based compost as a source of novel cellulolytic strains and enzymes. FEMS Microbiol Lett 339(2):93-101. doi:10. 1111/1574-6968.12057

Amore A, Parameswaran B, Kumar R, Birolo L, Vinciguerra R, Marcolongo L, Ionata E, La Cara F, Pandey A, Faraco V (2015) Application of a new xylanase activity from Bacillus amyloliquefaciens XR44A in brewer's spent grain saccharification. J Chem Technol Biotechnol 90:573-581. doi:10.1002/jctb.4589

Brethauer S, Studer MH, Wyman CE (2014) Application of a slurry feeder to 1 and 3 stage continuous simultaneous saccharification and fermentation of dilute acid pretreated corn stover. Bioresour Technol 170:470-476. doi:10.1016/j.biortech.2014.07.049

Brethauer S, Wyman CE (2010) Review: continuous hydrolysis and fermentation for cellulosic ethanol production. Bioresour Technol 101: 4862-4874. doi:10.1016/j.biortech.2009.11.009

Caspeta L, Caro-Bermúdez MA, Ponce-Noyola T, Martinez A (2014) Enzymatic hydrolysis at high-solids loadings for the conversion of agave bagasse to fuel ethanol. Appl Energy 113:277-286. doi:10. 1016/j.apenergy.2013.07.036

Choi IS, Lee YG, Khanal SK, Park BJ, Bae H-J (2015) A low-energy, cost-effective approach to fruit and citrus peel waste processing for bioethanol production. Appl Energy 140:65-74. doi:10.1016/j. apenergy.2014.11.070

Dasari RK, Dunaway K, Berson RE (2009) A scraped surface bioreactor for enzymatic saccharification of pretreated corn stover slurries. Energy Fuel 23:492-497. doi:10.1021/ef800434u CCC: $\$ 40.75$

Devantier R, Pedersen S, Olsson L (2005) Characterization of very high gravity ethanol fermentation of corn mash. Effect of glucoamylase dosage, pre-saccharification and yeast strain. Appl Microbiol Biotechnol 68:622-629. doi:10.1007/s00253-005-1902-9

Du J, Zhang F, Li Y, Zhang H, Liang J, Zheng H, Huang H (2014) Enzymatic liquefaction and saccharification of pretreated corn stover at high-solids concentrations in a horizontal rotating bioreactor. Bioprocess Biosyst Eng 37:173-181. doi:10.1007/s00449-0130983-6

Fagnano M, Impagliazzo A, Mori M, Fiorentino N (2015) Agronomic and environmental impacts of giant reed (Arundo donax L.): results from a long-term field experiment in hilly areas subject to soil erosion. Bioenerg Res 8:415-422. doi:10.1007/s12155-014-9532-7

Fan ZL, South C, Lyford K, Munsie J, van Walsum P, Lynd LR (2003) Conversion of paper sludge to ethanol in a semicontinuous solidsfed reactor. Bioprocess Biosyst Eng 26:93-101. doi:10.1007/ s00449-003-0337-x 
Giacobbe S, Vincent F, Faraco V (2014) Development of an improved variant of GH51 $\alpha$-L-arabinofuranosidase from Pleurotus ostreatus by directed evolution. New Biotechnol 31(3):230-236. doi:10.1016/ j.nbt.2014.02.004

Gupta R, Kumar S, Gomes J, Kuhad RC (2012) Kinetic study of batch and fed-batch enzymatic saccharification of pretreated substrate and subsequent fermentation to ethanol. Biotechnol Biofuels 20:5-16. doi:10.1186/1754-6834-5-16

Gusakov AV, Sinitsyn AP, Klyosov AA (1985) Kinetics of the enzymatic hydrolysis of cellulose: 1 . A mathematical model for a batch reactor process. Enzyme Microb Technol 7:346-352. doi:10.1016/01410229(85)90114-0

Han M, Moon SK, Choi GW (2014) Pretreatment solution recycling and high-concentration output for economical production of bioethanol. Bioprocess Biosyst Eng 37:2205-2213. doi:10.1007/s00449-0141198-1

He Y, Zhang L, Zhang J, Bao J (2014) Helically agitated mixing in dry dilute acid pretreatment enhances the bioconversion of corn stover into ethanol. Biotechnol Biofuels 7:1-13. doi:10.1186/1754-68347-1

Ingesson H, Zacchi G, Yang B, Esteghlalian AR, Saddler JN (2001) The effect of shaking regime on the rate and extent of enzymatic hydrolysis of cellulose. J Biotechnol 88:177-182. doi:10.1016/S01681656(01)00273-5

Iqbal HMN, Kyazze G, Keshavarz T (2013) Advances in the valorization of lignocellulosic materials by biotechnology: an overview. Biores 8(2):3157-3176

Isci A, Himmelsbach JN, Strohl J, Pometto AL III, Raman DR, Ane RP (2009) Pilot-scale fermentation of aqueous-ammonia-soaked switchgrass. Appl Biochem Biotechnol 157:453-462. doi:10.1007/ s12010-008-8235-y

Ishola MM, Jahandideh A, Haidarian B, Brandberg T, Taherzadeh MJ (2013) Simultaneous saccharification, filtration and fermentation (SSFF): a novel method for bioethanol production from lignocellulosic biomass. Bioresour Technol 133:68-73. doi:10.1016/j. biortech.2013.01.130

Jin M, Gunawan C, Balan V, Yu X, Dale BE (2013) Continuous SSCF of AFEXTM pretreated corn stover for enhanced ethanol productivity using commercial enzymes and Saccharomyces cerevisiae 424A (LNH-ST). Biotechnol Bioeng 110(5):1302-1311. doi:10.1002/bit. 24797

Jørgensen H, Kristensen JB, Felby C (2007a) Enzymatic conversion of lignocellulose into fermentable sugars: challenges and opportunities. Biofuel Bioprod Bioref 1:119-134. doi:10.1002/bbb.4

Jørgensen H, Vibe-Pedersen J, Larsen J, Felby C (2007b) Liquefaction of lignocellulose at high-solids concentrations. Biotechnol Bioeng 96(5):862-870. doi:10.1002/bit.21115

Kadam KL, Rydholm EC, McMillan JD (2004) Development and validation of a kinetic model for enzymatic saccharification of lignocellulosic biomass. Biotechnol Prog 20:698-705. doi:10.1021/ bp034316x CCC: $\$ 27.50$

Kadić A, Palmqvist B, Lidén G (2014) Effects of agitation on particle-size distribution and enzymatic hydrolysis of pretreated spruce and giant reed. Biotechnol Biofuels 7:77-86. doi:10.1186/1754-6834-7-77

Kajaste R (2014) Chemicals from biomass - managing greenhouse gas emissions in biorefinery production chains - a review. J Clean Prod 75:1-10. doi:10.1016/j.jclepro.2014.03.070

Khanal SK, Montalbo M, van Leeuwen J, Srinivasan G, Grewell D (2007) Ultrasound enhanced glucose release from corn in ethanol plants. Biotechnol Bioeng 98:978-985. doi:10.1002/bit.21497

Khoo HH (2015) Review of bio-conversion pathways of lignocelluloseto-ethanol: sustainability assessment based on land footprint projections. Renew Sust Energ Rev 46:100-119. doi:10.1016/j.rser.2015. 02.027

Kim SM, Guo J, Kwak S, Jin YS, Lee DK, Singh V (2015) Effects of genetic variation and growing condition of prairie cordgrass on feedstock composition and ethanol yield. Bioresour Technol 183: 70-77. doi:10.1016/j.biortech.2015.02.020

Kim TH, Choi CH, Oh KK (2013) Bioconversion of sawdust into ethanol using dilute sulfuric acid-assisted continuous twin screw-driven reactor pretreatment and fed-batch simultaneous saccharification and fermentation. Bioresour Technol 130:306-313. doi:10.1016/j. biortech.2012.11.125

Kristensen JB, Felby C, Jorgensen H (2009) Yield-determining factors in high-solids enzymatic hydrolysis of lignocellulose. Biotechnol Biofuels 2(1):11-20. doi:10.1186/1754-6834-2-11

Lee D, Yu AHC, Saddler JN (1994) Evaluation of cellulase recycling strategies for the hydrolysis of lignocellulosic substrates. Biotechnol Bioeng 45:328-336. doi:10.1002/bit.260450407

Liguori R, Amore A, Faraco V (2013) Waste valorization by biotechnological conversion into added value products. Appl Microbiol Biotechnol 97:6129-6147. doi:10.1007/s00253-013-5014-7

Liguori R, Soccol CR, de Souza Vandenberghe LP, Woiciechowski AL, Faraco V (2015) Second generation ethanol production from brewers' spent grain. Energies 8:2575-2586. doi:10.3390/ en8042575

Limayem A, Ricke SC (2012) Lignocellulosic biomass for bioethanol production: current perspectives, potential issues and future prospects. Prog Energ Combust 38:449-467. doi:10.1016/j.pecs.2012. 03.002

Lin YS, Lee WC (2011) Simultaneous saccharification and fermentation of alkaline pretreated cogongrass for bioethanol production. BioResources 6:2744-2756

Lin YS, Lee WC, Duan KJ, Lin YH (2013) Ethanol production by simultaneous saccharification and fermentation in rotary drum reactor using thermotolerant Kluyveromyces marxianus. Appl Energy 105: 389-394

Lu Y, Yang B, Gregg D, Saddler JN, Mansfield SD (2002) Cellulase adsorption and an evaluation of enzyme recycle during hydrolysis of steam exploded softwood residues. Appl Biochem Biotechnol 98(100):641-654. doi:10.1385/ABAB:98-100:1-9:641

Ludwig D, Michael B, Hirth T, Rupp S, Zibek S (2014) High solids enzymatic hydrolysis of pretreated lignocellulosic materials with a powerful stirrer concept. Appl Biochem Biotechnol 172:16991713. doi:10.1007/s12010-013-0607-2

Modenbach AA, Nokes SE (2012) The use of high-solids loadings in biomass pretreatment - a review. Biotechnol Bioeng 109:1430 1442. doi:10.1002/bit.24464

Mohagheghi A, Tucker M, Grohmann K, Wyman C (1992) High solids simultaneous saccharification and fermentation of pretreated wheat straw to ethanol. Appl Biochem Biotechnol 33:67-81. doi:10.1007/ BF02950778

Montalbo-Lomboy M, Johnson L, Khanal SK, van Leeuwen J, Grewell D (2010a) Sonication of sugary-2 corn: a potential pretreatment to enhance sugar release. Bioresour Technol 101(1):351-358. doi:10. 1016/j.biortech.2009.07.075

Montalbo-Lomboy M, Khanal SK, van Leeuwen JH, Raman DR, Dunn L, Grewell D (2010b) Ultrasonic pretreatment of corn slurry for saccharification: a comparison of batch and continuous systems. Ultrason Sonochem 17:939-946. doi:10.1016/j.ultsonch.2010.01. 013

Nitayavardhana S, Rakshit SK, van Leeuwen J, Grewell D, Khanal SK (2008) Ultrasound pretreatment of cassava chip slurry to enhance sugar release for subsequent ethanol production. Biotechnol Bioeng 101(3):487-496. doi:10.1002/bit.21922

Okur MT, Saraçoglu NE (2006) Ethanol production from sunflower seed hull hydrolysate by Pichia stipitis under uncontrolled $\mathrm{pH}$ conditions in a bioreactor. Turkish J Eng Env Sci 30:317-322

Olofsson K, Palmqvist B, Lidén G (2010a) Improving simultaneous saccharification and co-fermentation of pretreated wheat straw using both enzyme and substrate feeding. Biotechnol Biofuels 3:17-25. doi:10.1186/1754-6834-3-17 
Olofsson K, Rudolf A, Lidén G (2008) Designing simultaneous saccharification and fermentation for improved xylose conversion by a recombinant strain of Saccharomyces cerevisiae. J Biotechnol 134: 112-120. doi:10.1016/j.jbiotec.2008.01.004

Olofsson K, Wiman M, Lidén G (2010b) Controlled feeding of cellulases improves conversion of xylose in simultaneous saccharification and cofermentation for bioethanol production. J Biotechnol 145:168175. doi:10.1016/j.jbiotec.2009.11.001

Palmqvist B, Lidén G (2012) Torque measurements reveal large process differences between materials during high solid enzymatic hydrolysis of pretreated lignocellulose. Biotechnol Biofuels 5:57-65. doi: 10.1186/1754-6834-5-57

Palmqvist E, Hahn-Hägerdal B, Galbe M, Larsson M, Stenberg K, Szengyel Z, Tengborg C, Zacchi G (1996) Design and operation of a bench-scale process development unit for the production of ethanol from lignocellulosics. Biores Technol 58:171-179. doi:10. 1016/S0960-8524(96)00096-X

Philippidis GP, Hatzis C (1997) Biochemical engineering analysis of critical process factors in the biomass-to-ethanol technology. Biotechnology Prog 13:222-231. doi:10.1021/bp970017u

Pihlajaniemi V, Sipponen S, Sipponen MH, Pastinen O, Laakso S (2014) Enzymatic saccharification of pretreated wheat straw: comparison of solids-recycling, sequential hydrolysis and batch hydrolysis. Biores Technol 153:15-22. doi:10.1016/j.biortech.2013.11.060

Popp J, Lakner Z, Harangi-Rákos M, Fári M (2014) The effect of bioenergy expansion: food, energy, and environment. Renew Sust Energ Rev 32:559-578. doi:10.1016/j.rser.2014.01.056

Riedlberger P, Weuster-Botz D (2010). Rührorgan für Flüssigkeiten. German Patent Application DE 202010011902 U1

Riedlberger P, Weuster-Botz D (2012) New miniature stirred-tank bioreactors for parallel study of enzymatic biomass hydrolysis. Biores Technol 106:138-146. doi:10.1016/j.biortech.2011.12.019

Rodrigues AC, Leitão AF, Moreira S, Felby C, Gama M (2012) Recycling of cellulases in lignocellulosic hydrolysates using alkaline elution. Bioresour Technol 110:526-533. doi:10.1016/j. biortech.2012.01.140

Sadana A (1992) Models of enzyme deactivation. In: Gupta MN (ed) Thermostability of enzymes. Narosa, New Delhi, pp 84-93

Salmon DNX, Rigon Spier M, Soccol CR, de Souza Vandenberghe LP, Weingartner Montibeller V, Jucoski Bier MC, Faraco V (2014) Analysis of inducers of xylanase and cellulose activities production by Ganoderma applanatum LPB MR-56. Fungal Biol 118:655662. doi:10.1016/j.funbio.2014.04.003

Scheidel A, Sorman AH (2012) Energy transitions and the global land rush: ultimate drivers and persistent consequences. Global Environ Chang 22:588-595. doi:10.1016/j.gloenvcha.2011.12.005

Shahsavarani H, Hasegawa D, Yokota D, Sugiyama M, KaneKo Y, Boonchird C, Marashima S (2013) Enhances bio-ethanol production from cellulose materials by semi-simultaneous saccharification and fermentation using high temperature resistant Saccharomyces cerevisiae TJ14. J Biosci Bioeng 115:20-23. doi:10.1016/j.jbiosc. 2012.07.018
Svetlitchnyi VA, Kensch O, Falkenhan DA, Korseska SG, Lippert N, Prinz M, Sassi J, Schickor A, Curvers S (2013) Single-step ethanol production from lignocellulose using novel extremely thermophilic bacteria. Biotechnol Biofuels 6:31. doi:10.1186/1754-6834-6-31

Szijártó N, Horan E, Zhang J, Puranen T, Siika-aho M, Viikari L (2011a) Thermostable endoglucanases in the liquefaction of hydrothermally pretreated wheat straw. Biotechnol Biofuels 4:2-11. doi:10.1186/ 1754-6834-4-2

Szijártó N, Siika-Aho M, Sontag-Strohm T, Viikari L (2011b) Liquefaction of hydrothermally pretreated wheat straw at highsolids content by purified Trichoderma enzymes. Bioresour Technol 102:1968-1974. doi:10.1016/j.biortech.2010.09.012

Tengborg C, Galbe M, Zacchi G (2001) Influence of enzyme loading and physical parameters on the enzymatic hydrolysis of steam-pretreated softwood. Biotechnol Prog 17: 110-117. doi: 10.1021/bp000145+ CCC: $\$ 20.00$

Ventorino V, Aliberti A, Faraco V, Robertiello A, Giacobbe S, Ercolini D, Amore A, Fagnano M, Pepe O (2015) Exploring the microbiota dynamics related to vegetable biomasses degradation and study of lignocellulose-degrading bacteria for industrial biotechnological application. Sci Rep 5:8161-8174. doi:10.1038/srep08161

Wahlbom CF, van Zyl WH, Jonsson LJ, Hahn-Hägerdal B, Otero RRC (2003) Generation of the improved recombinant xylose-utilizing Saccharomyces cerevisiae TMB 3400 by random mutagenesis and physiological comparison with Pichia stipitis CBS 6054. FEMS Yeast Res 3:319-326. doi:10.1016/S1567-1356(02)00206-4

Wang Z, Xu J, Cheng JJ (2011) Modeling biochemical conversion of lignocellulosic materials for sugar production: a review. Biores 6(4):5282-5306

Mezule WL, Dalecka B, Juhna T (2015) Fermentable sugar production from lignocellulosic. Chem Eng Trans 43:619-624. doi:10.3303/ CET1543104

Weingartner Montibeller V, de Souza Vandenberghe LP, Amore A, Soccol CR, Birolo L, Vinciguerra R, Salmon DNX, Rigon Spier M, Faraco V (2014) Characterization of hemicellulolytic enzymes produced by Aspergillus niger NRRL 328 under solid state fermentation on soybean husks. BioRes 9(4):7128-7140

Wingren A, Galbe M, Zacchi G (2003) Techno-economic evaluation of producing ethanol from softwood: comparison of SSF and SHF and identification of bottlenecks. Biotechnol Prog 19:1109-1117. doi: 10.1021/bp0340180

Wooley R, Ruth M, Sheehan J, Ibsen K, Majdeski H, Galvez A (1999) Lignocellulosic biomass to ethanol process design and economics utilizing cocurrent dilute acid prehydrolysis and enzymatic hydrolysis: current and futuristic scenarios, National Renewable Energy Laboratory, Golden, CO, NREL/TP-580-26157

Zhang J, Chu D, Huang J, Yu Z, Dai G, Bao J (2010) Simultaneous saccharification and ethanol fermentation at high corn stover solids loading in a helical stirring bioreactor. Biotechnol Bioeng 105(4): 718-728. doi:10.1002/bit.22593 